\title{
The Dynamics of Political Communcation in the South Kalimantan Society
}

\author{
$1^{\mathrm{st*}}$ Bachruddin Ali Akhmad \\ Communication Science \\ Universita Lambung Mangkurat \\ Banjarmasin, Indonesia \\ bachruddin.01@gmail.com
}

\author{
$2^{\text {nd }}$ Sarwani \\ Communication Science \\ Universita Lambung Mangkurat \\ Banjarmasin, Indonesia \\ sarwani78@yahoo.com \\ $4^{\text {th }}$ Muhammad Muthahhari Ramadhani \\ Communication Science \\ Universita Lambung Mangkurat \\ Banjarmasin, Indonesia \\ muthahhari.ramadhani@ulm.ac.id
}

\author{
$3^{\text {rd }}$ Sri Astuty \\ Communication Science \\ Universita Lambung Mangkurat \\ Banjarmasin, Indonesia \\ City, Country \\ Sri_astuty@ulm.ac.id
}

\begin{abstract}
The people of South Kalimantan are famous for their religious community and tend to have a very strong Islamic context. In daily behavior, the people of South Kalimantan prioritize the teachings of religious leaders and scholars, especially charismatic scholars. The purpose of this study was to analyze the dynamics of political communication in the community in South Kalimantan. The approach used is a qualitative approach. The object of this research is the people of South Kalimantan, especially in the area of Banjarmasin City and Banjar Regency. The interview method used is snowball. This study took place in South Kalimantan which included 11 cities and districts using ethnography. The result in the development of advanced technology, people must be more daring to change in making decisions. The communication dynamics of the people of South Kalimantan tend not to be dynamic because they prioritize linear communication patterns. Developing literacy about various things must be improved, especially in the social, legal, religious and social life fields. The dynamics of communication in the people of South Kalimantan tend to have less than maximum efforts, because they only accept fate in accordance with the role models of religious leaders and Ulama they profess.
\end{abstract}

Keywords- Political Communication, Religious Leaders, Linear Communication Patterns, South Kalimantan, Political Banality

\section{INTRODUCTION}

The people of South Kalimantan are famous for their religious community and tend to have a very strong Islamic context. In daily behavior, the people of South Kalimantan prioritize the teachings of religious leaders and scholars, especially charismatic scholars. For example, the winners of the Elected DPD Members in the 2019-2024 Period in the South Kalimantan Province (South Kalimantan), three of the four elected DPD candidates were politicians with the title "Habib" including: Habib Abdurrahman Bahasyim, Habib Zakaria, Habib Hamid Abdullah and Gusti Farid Hasan Aman who has not have habib title but has Gusti title which is a cultural custom of the Banjar Tribe. Everything good relating to social, cultural, and political always follow the direction and advice of religious leaders and scholars who believe [2]. This is interesting because not all religious leaders and scholars know about aspects that are not scientific. Communication patterns that emerge in society are not heterogeneous communication patterns but linear communication patterns which are unidirectional communication patterns (what he likes and thinks is right).

In the South Kalimantan region, the main ethnic groups are residents whose status is "Urang Banjar". This term does not only mean the Banjar tribe, but also the location of the mukim, because Urang Banjar can mean the Banjar tribe who live in the upstream area of the river alias "the Banjar people preliminary", or the Banjar tribe who live around the Barito river estuary, called "the Banjar kuala ". Residents of the "Banjar kuala" group traditionally settled in the Banjarmasin City area (around the Alalak and Kuwin rivers), in the Banjar District (around the Martapura river), and in the Barito Kuala Regency (around the Marabahan river) [1].

Although their cultural history is different, Banjar people (introduction and kuala) are a solid community when it comes to religious beliefs. Nearly one hundred percent of Banjar people are followers of Islam. But uniquely, the same religious status does not make Banjar people automatically feel "related" to migrants from Java and Sulawesi. Banjar people tend to feel very different from those whose ethnic groups are Javanese or Bugis and Makassarese even though members of that ethnic group are Muslim. Geographically, the population of South Kalimantan which is dominant with Javanese ethnic groups is mainly in the areas of Tanah Laut, Tanah Bumbu and Batola as a result of the transmigration program in the past. While the population which is characterized by Bugis and Makassar ethnicity is mainly residents who live around the coastal area of Tanah Bumbu Regency and Kotabaru Regency [2].

This characterization of ethnicity is important in the political communication in South Kalimantan, because it is almost certain that "Urang Banjar" will not choose non-Banjar candidates. Non-Banjar people, especially from Javanese ethnic groups, seem to be trying to carry out the process of acculturation and assimilation into "Urang Banjar". In this case marriages between Banjarese and Javanese are very common, and Javanese rarely use Javanese except when 
speaking exclusively in their communities. Because of that ethnicity sentiment is actually quietly buried. Only because of political interests for a moment, the matter that has been buried and then often dismantled again (by certain elites) for the purpose of winning victory in political contestation and depends on their political communications [6].

Limited, and very small in number, in South Kalimantan there are also other ethnic groups such as Madurese and Batak, or even Arab and Chinese races. Because the numbers are so small, their position in the political universe never stands out. Moreover, their social life tends to be exclusive, and this can be proven from the names of the locations of their settlements such as Kampung Arab, Chinatown, and Kampung Gedang (for Madurese in Banjarmasin), whereas Batak people do not even have the name of their village [1].

The people of South Kalimantan have a tendency to be obedient and obedient to those who have a "title" of ulama and habib because they are considered as role models and figures who master about religion, especially Islam. In fact those who previously had the title as habib or as ulama were also much involved in politics which was in contrast to the initial background as "habib" and "ulama" engaged in religion.

Therefore, there should be other factors that determine the quality of social networks which then determine the partisanship of the supporting masses. From field observations, culturally it is possible, and it can be classified on: (1) zuriat relations based on religious primordialism; and (2) zuriat relations based on "bubuhan"[4].

Zuriat relations based on religious primordialism can be understood in the perspective of Urang Banjar social coating. Traditionally, the Banjar people glorified people who mastered the science of religion (Islam), as "Orang Alim". According to its history, Islam is the "state religion" for the Banjar Kingdom, so that for most of the population in South Kalimantan, as descendants of the people of the Banjar Kingdom, the status of the Islamic religion is more as "hereditary religion" and they never questioned why religion Islam. As a "hereditary religion", members of the Banjar community have studied Islam since they were very young, and one of the things taught is: they must respect their parents and religious teachers. In the social sphere, the obligatory religion teacher appears in the personification of Tuan Guru, who is culturally called a "pious person"[3].

It is the "pious people" who get the highest honor in the social structure of the traditional Banjar community. That is why, even the Regional Head, as the personification of the ruler in the modern era, should not be in a higher position than the "pious people". Regional heads and officials (civil and military) may only be in the next layer after the pious. At the lower levels of the officials came their status included in the category of "rich people" (Banjar: urang sugih), employees (or "office people"), and finally the jaba (aka "common people" or the people usual). In later developments, namely after the socio-economic life of the people became more open and social stratification became increasingly unclear, the social structure of Urang Banjar became liquid and mixed. Even in some cases, "Tuan Guru" (as part of the pious universe) can at the same time have material wealth equivalent to rich people. This is possible because the Master also often has a private business that causes him to be rich $\sim$ even though there has never been a rich person who suddenly became a "pious person" and socially recognized his wisdom with his informal communications [1].

The people of South Kalimantan, especially the middle to lower level, have a physically poor outlook, but when asked if they feel happy, the answer is happy, because based on the "Ulama" he believes it is in accordance with the religious views of the middle to lower level society. the purpose of this study was to analyze the dynamics of political communication in the community in South Kalimantan especially from religion and culture perspective.

\section{LITERATURE REVIEW}

\section{A. Political Communication}

After a decade of political and administrative reform and several rounds of competitive elections, Indonesia, by most accounts, displays a democratic political system. There is little consensus on the character of the country's democracy, however. Optimists have called Indonesia one of Southeast Asia's most vibrant democracies, a claim that, upon a moment's reflection, says remarkably little. It is no coincidence that many sunny accounts of Indonesia's politics are fixated on Jakarta and national politics, providing a decidedly thin understanding of the actual state of Indonesia's political institutions. By contrast, analysts of the country's local politics, though cognizant and appreciative of the country's significant democratic gains, have presented evidence that questions the quality of the country's democratic institutions [16].

Indonesia's formal democratic institutions remain vulnerable to patrimonial manipulation in the context of an increasingly competitive and oligarchic struggle for decentralized power and governance. The previous work suggests that economic considerations play a more important role in the formation of citizens' political choices and opinions in poorer societies. Various explanations can help in turn to understand why political considerations are more important in richer countries [18]. In this case the first, economic issues should be less salient for individuals in affluent nations since they are less exposed to the types of circumstances that make material considerations more pressing in developing countries (Rodrick,2001; Rohrschneider and Loveless, 2010; Singer, 2011). Second, political considerations should matter more in richer nations as a considerable body of work has shown that economic development sustains the quality of democratic institutions and make citizens focusing more on political processes and perceptions of elites' responsiveness to their concerns (Lipset, 1959; Linz and Stepan, 1996; Dalton et al., 2007; Rohrschneider and Loveless, 2010; Norris, 2011; Dahlberg et al., 2015; Reher, 2015). Third, economic concerns should be less present and political considerations more visible in public debates in affluent nations given that the media and political parties tend to take their cues from voters and emphasize issues that are salient in the minds of citizens (Ansolabehere and Iyengar, 1994; Klüver and Sagarzuzu, 2016), a point that Burlacu (2014: 179) nicely encapsulates when she wrote that "in wealthy countries, other factors than the economic growth get on the public agenda during the elections." The preceding considerations, and arguments derived from theories of issue salience (Krosnick, 1990; Fournier et al., 2003; Chong and Druckman, 2007; Rohrschneider and Loveless, 2010) or information theory of attitude formation (Higgins and King Gillian, 1981; Bizer et 
al., 2001) neatly suggest that political considerations should be more accessible and relevant to citizens in richer countries in assessing their political institutions [17].

\section{B. Reconstruction of Political Banality}

The In fact, the terms 'banal' and 'banality' are usually used in social philosophy to describe the superficial understanding of someone in observing or valuing an entity. As a result he can change someone's perception of the entity. Or even trigger a person's behavior and actions according to the perception built from the results of his understanding. Thus, 'banal' and 'banality' are actually just terms, and for the same purpose other terms can be used. Although the titles are different, banal is a real phenomenon, which is sometimes justified by the mystification of reality. Therefore this term will be more meaningful if you look at the context [1].

Banal phenomena and banality in the context of the meaning of religious values and consumerism themes, due to the fact, religion is often a place to escape from life bound by material aspects.

Banality, when embodied in a political act, may represent despicable and rotten actions. Therefore political crime can be justified by the presence of political banality, however, political banality is not a political crime itself. Political banality is perhaps more appropriate if it is positioned as a conditional supporting factor, and political crime is the result. Because of that, political banality can actually be positioned as an intervening variable of a rotten political act, political fraud, or whatever factors influence the quality of political democracy[11].

In other words, ethical issues, or rather moral issues, are the main issues in political banality. The problem is that political morality is often only considered a philosophical problem, because it is difficult to measure indicators and validity empirically. In fact, various moral systems are impossible to compare and evaluate differentially[12].

Political banality which involves the implementation of the idea of political democratization, at various levels, is actually a performance of actors who are not easily verified, validated and confirmed on what and why they are to carry out banal actions [2].

\section{Patterns of Leadership and Negotiation in the realm of Local Politics}

To address these issues, we start by defining democracy as a system of rule in which citizens choose their leaders by voting in elections (Przeworski, 1991) and operationalize regime type accordingly as being either electoral democracy or non-democracy. While not the only solution to questions of what political regime types comprise, we believe this choice suits research on population health for a number of reasons. In comparison with measures of the 'level' of democracy, a binary variable makes the analogy to a naturalistic experiment especially plausible, allowing an average difference between 'electoral democracies' and 'non-democracies' to be quantified and discussed. Secondly, measures that alternatively use the more encompassing conceptualization schemes for political regime type can often be broken down into subcomponent measures that distinguish each country's electoral process from other putative elements of democracy. Thefocus on electoral as opposed to other types of democracy allows for these other, distinctly political components to be tested as possible mediators [22]. Arguably, political leaders will take this into account asthey devise the country's economic policies, or else risk losing a significant portion of their constituency to a competitor. [23].

According to the theory of exchange (exchange theory)[7], the concept of leadership is almost always associated with 'rewards' (reward), because rewarded is one of the important variables in influencing individuals (including bureaucrats)'. So, the hope of making a profit and calculating the costs to be incurred is one of the motives for bureaucrats' behavior (including politicians). What is used as a means of negotiation (exchange tools) are the resources owned by bureaucrats including: money, information and authority in the form of goods and services [8].

But besides the motive and motivation factors, it is also necessary to pay attention to the atmosphere of communication that occurs, especially in the lobbying and negotiation process. In effective communication, the parties to the debate can understand each other better, it can be estimated that the differences between them can be reduced and through negotiations it is possible to reach a previous agreement. In the situation of lobbying and negotiating the act of influencing others is part of everyday life, including trying to influence the attitudes of others and trying to make others understand the communicator's words. In the lobby, a person can choose the right words, prepare well in advance and express them correctly too, then it will produce excellent communication. However, the effectiveness of communication as a whole still requires a positive and trusting psychological atmosphere.

Negotiations will not occur if one party has the authority or power as a party to impose a decision on the other party. Negotiation does not consist of skill alone. In a broad sense with regard to the subject matter, the nature of the parties involved, and the level of formality. Negotiations have different qualities depending on those involved in the negotiations, on their own behalf or as representatives (Lewicki, 2013, pp. 5-10). In the case that there is a party that represents someone, then the culprit is often referred to as an "intermediary" (negotiator), and he is usually a trusted person of the negotiating party [6].

\section{RESEARCH METHOD}

The approach used is a qualitative approach. The object of this research is the people of South Kalimantan, especially in the area of Banjarmasin City and Banjar Regency. The interview method used is snowball. When the information needed is deemed saturated, the interview with key informants ends. The method of determining the resource persons is by determining the key informants namely Habib Abdurahman Bahasyim and Habib Zakaria. Supporting informants are participants who have attended certain religious assemblies, especially in Banjar District and Banjarmasin City. This study took place in South Kalimantan which included 11 cities and districts using ethnography communication.

\section{RESULT AND DISCUSSION}

The communication dynamics of the people of South Kalimantan tend not to be dynamic because they prioritize linear communication patterns. Heterogeneous communication arises in a plural society that arises because of the existence of several different ethnic groups both social and cultural as well as mindset, a separate problem in the relations 
between ethnic and religious groups. Martodirdjo (2000.p 3), argues that the issue of ethnicity is one of the complex social phenomena that is central in the framework of the totality of people's lives. The issue of ethnicity is in direct contact with all aspects of human life both communication, economic, social, political, moral, spiritual, and physical aspects. In terms of plurality ethnicity it is usually characterized by ethnocentrism, which is a kind of understanding that considers its own culture better than the culture of other people or other groups[14].

As stated in the previous section that the people who inhabit Indonesian territory are very diverse, in the sense that it consists of various ethnic group. Politics and religions, each of which has different customs from one another. The plurality of the community on one hand is an invaluable gift and wealth, this is because of the plural society, of course, stored a variety of cultural potential. On the other hand, the diversity of the community can also lead to various conflicts that are not impossible to lead to conflict, because there is a miss communication in social interaction both within and outside the community environment [5].

Local politics is essentially the practice of structures and political systems that apply in certain locations, namely provincial or district / city government areas. The dynamics of local politics shows the state of the ups and downs of dominant power from one period to another. In this case, the Dynamics of Political Communication in southern Kalimantan, the concept of ethnicity shifted from the traditional concept to the modern concept, the track record of a person in the area, especially for religious leaders in the political sphere, is no longer a blood relation but an already modern relationship. even so the concept of religion is still strong for the determination to get a voice or influence.

In the context of South Kalimantan, Islamic politics is quite dominant, and has experienced a brilliant period in the early era of independence, during liberal democracy, and in the reform era. When marginalized, Islamic politics was experienced in the era of guided democracy and throughout the reign of the new regime. In the reform era, the rise of Islamic politics was triggered by the enactment of law number 32 of 2004 concerning regional governments, which mandated direct elections of regional heads, so that Islamic politics gained its space to show its existence again. This is marked by the appearance of Islamic political power into local political power, where the Islamic party has always been accumulatively dominant in the vote in the legislative body. Likewise, in the executive branch, governors and regents / mayors elected are dominated by candidates promoted by Islamic parties.

For the example of Ethnicity shifting, the traditional concept to the modern concept, the track record of someone in the area (no longer a blood relation) of religion is still a strong determination. Islamic politics from 1955-present. The dynamics of political communication with people's identities, for example the basis of political parties in South Kalimantan is dominated by figures who are Muslim. For example, there is a photo of a religious figure displayed wrongly one regional head namely the Governor of South Kalimantan for the period of 2010-2015 by kissing hands to religious teachers. This is an important value because the fanatical symbol is still very famous.
In the current reform era, local politics in South Kalimantan shows its independence and function by becoming a bridge of all political interests at the national level, which has an impact on the emergence of local political actors and institutions appearing ahead. Islamic political orientation, political strategy "bubuhan" plays a role again and allows the raising of primordial issues in the post-conflict local election.

The power of the media plays a role through its existence as an institution and in the production process that occurs within itself. Its role as an institution can manifest in two alternatives, as a public space or as a profit-producing institution for its owner (owner). Judging from the production process, many factors that suppress or influence the media frame reality of political figures or even non-indigenous religious figures from the Banjar tribe so that political communication that occurs may be inaccurate because it is hampered by related ethnic and culture.

In this case there is a battle of frames about the interpretation of the slogan 'Habib Urang Banua' which is the interpretation of Habib Urang Banua' as a person or politician domiciled in the Banua region or in South Kalimantan and someone who has a devotion to the Banua region and mostly more religious than another participant. In another frame, there is an interpretation in the context of ethnic identity, a person of ethnic Banua or Banjar. The slogan 'Original Urang Banua' is defined as a region / region in the context of the criteria for a candidate for governor. Second, in the context of gaining support from the community / voters in the postconflict local election, the elements of Asli Urang Banua are interpreted as ethnic, namely the Banjar ethnicity, which is the slogan of primordialism. Thus the frame of primordialism is used still in a negative context, only used as a persuasive tool for group-oriented.

Besides being used as a differentiator / differentiator, primordialism is also used by the media to form associative frames. Through this frame, local political figures are identified as having the capacity of ulama. The importance of this, due to scholars as the core, became a dominant follow-up of all South Kalimantan communities. Being perceived as cagub with the capacity of ulama means that it will also be dominantly supported by voters. Therefore, the use of the issue of 'traditional authority / ulama' has associated local leaders who have strength and authority and values as ulemas of South Kalimantan, which will move the voters of the banjar to choose political figures who carry the slogan 'Asli Urang Banua' and override multicultural aspects.

Free and fair elections are assumed to demand a 'level playing field' for political contestants. That is, the candidates must get the same opportunities in the context of contestation. Such is the common thread of the principle of honesty and fairness in the rules of a general election, and the Regional Election contest is no exception. But if we refer to Bourdieu, that assumption is actually illogical. In games that take place in social spaces or competitive fields, which involve various social agents, actors use different strategies to maintain or improve their position. What is at stake in the field is capital accumulation "which in the process of capital then creates a field (realm) where the social agent is risking all of his possessions". Bourdieu nominates four forms of capital, namely: economy (money and assets); cultural (eg forms of knowledge, taste, aesthetic and cultural preferences, and 
language); social (eg affiliations and networks, family, religious and cultural heritage) and symbolic (everything that forms other capital and can be "exchanged" in other fields, such as credentials) [11]. However, unlike playing on a soccer field that depends on the conditions on the pitch, there is no level of play in the social sphere "because players who start with certain forms of capital they have benefited from the start because the playing field depends on the capital they own and produce". These lucky players can use their capital gains to gather more and more advanced (more successful) than others [12].

In the case of the post-conflict local election, the patronage relationship may have been established for a long time because the patronage assistance must be repeated for a long time. But not all candidates can do that. The rational choice made by a particular candidate is to "borrow" a patron's good relationship with a suspected client network. That is why there are candidates who work hard to hold public figures who are known to have broad mass support. Or religious leaders, who serve as political partners in the hope that followers of religious leaders will support him.

The rationality of actors and their political actions is sometimes difficult to explore if they only look at their actions and the discourse developed to justify their actions. Referring to David Apter [28], when we will discuss political issues, it is necessary to agree in advance that political action is a symbolic capital that to be able to understand it requires interpretation related to the perspective and life experience of the person making the interpretation. That needs to be emphasized, because all the political terms that exist in political science references are actually a combination of various contexts involving long-term cycles and events that can be categorized as short-term cycles. Whereas in terms of meaning and content, the context of action in political life is everything. The reason is, he can give meaning to political events when viewed in terms of political communication. It creates an aura of understanding about a political phenomenon. It is the basis for the emergence of competition. He directed the factions. In other words, the context constructs meaning, and meaning itself creates context. Some contexts are wrapped exclusively, such as for example religion or nationalism. However, all social and political life is actually limited - among other things by different forms of social structure - one of which is to build a configuration or forms of structural analysis. And what then undermines these boundaries is what is considered good as political action, not only in the form of specific terms to justify an issue, but even concerning general terms, principles, political ethics, communication patterns and political theory alone.

In the other case recently in Elections 2019, The political actions of the candidate (and his Success Team) are more or less damaging the polite political order. Especially in later political developments, there was a discourse developed by frustrated community leaders, that "just accept the money, but don't choose the person". An ambiguous attitude from efforts to prevent evil by allowing wrongdoing. The discourse has become a kind of fatwa that "bribes" from candidates who fight in political contestation are "halal", provided that they do not vote for candidates who spread the money. In this connection there is clearly a kind of "opaque zone" in local politics. The banal political attitude that was transmitted to the voters could not be deciphered anymore, who offered money politics, and who needed it. But in general voter groups never ask for money for themselves, because what they ask for is assistance for the construction of public facilities. However, because banality has penetrated into people's behavior, they generally do not refuse to be given money by a certain candidate's Success Team, as long as there is no agreement to choose that particular candidate. Moreover, community leaders, including religious leaders, have not yet issued a "haram" fatwa to accept political money given by candidates during the campaign period.

Empirical data shows that the political actions of elites and actors are so dominant affecting voter behavior. Meanwhile voter groups also quietly have their own preferences about how political communication should be built by candidates. In this connection it is important to be answered academically, why there is a gap between what the formulator of the General Election regulation is about to share with the reality on the ground. The trajectory of history (background) what is behind it so that political changes that occur as if not followed by the development of the culture of the people involved in it. There are almost no instruments built by political party elites in order to be able to communicate directly and reciprocally with their cadres and sympathizers all the time. Political party elites tend to try to communicate intensely with their sympathizers just before the election

In terms of local politics and the aspect of the political communications the most powerful communication media as the main force is face to face through representatives of Ulama and political figures whose image is well seen by the public on the other hand local mass media is not neutral, because local media plays a role in bringing public opinion to the lower middle class most prominent. The communications patterns is depends of the symbols and visuals such as pictures of religious leaders (in example Guru Ijai as the most popular Ulama in South Kalimantan with the Regional Head).

\section{CONCLUSION}

In the development of advanced technology, people must be more daring to change in making decisions. Developing literacy about various things must be improved, especially in the social, legal, religious and social life fields. The dynamics of communication in the people of South Kalimantan tend to have less than maximum efforts, because they only accept fate in accordance with the role models of religious leaders and Ulama they profess. Political figures who must be smart in utilizing characteristics local people by utilizing interpersonal communication through religious and social doors can through mass media advetorial from team success and depends on the political communication adopted by the local leader. In this study, it is questionable why the anomaly in the form of political banality has taken place, which is marked by fraud and money politics, so that the national and regional elections in South Kalimantan becomes compromised if there are concerned about religion and culture.

\section{ACKNOWLEDGMENT}

Thank God, Allah SWT because of His blessing, the writing of this research can be completed well. If not because of God's help, surely all the obstacles and challenges that accompanied the process of writing this research could not be our responsibility. And also thank you to the committee and executors of the APIK-PTMA 2020 COMMUNICATION 
CONFERENCE activity with the theme Communication 4.0: Challenging Technology, Theory and Multiculturalism.

Thank you to the interviewees and research team who have worked hard in forming research results on local politics in South Kalimantan. We also thank you to the University of Lambung Mangkurat Banjarmasin, South Kalimantan, which is our homebase for lecturers and academics to channel knowledge and writing related to local politics and the dynamics of political communication in it.

\section{REFERENCES}

[1] M. Sarman. "Kerumpangan dan banalitas politik: praksis demokrasi politik di ranah lokal". Deepublish, Yogyakarta, Indonesia, 2017. (References)

[2] M. Sarman.. "Menuju Puncak Kekuasaan: Catatan Ringan dari Pilkada Kalimantan Selatan Tahun 2005”. 2005 (ISBN: 979-3381-06-0).

[3] M. Sarman,. "Pileg Overdosis". 2009 (ISBN: 979-338191-6).

[4] M. Sarman. "Pemilukada-Kada: Waham Seputar Pilkada Kalsel 2010". 2010

[5] Asia Pacific Handbook of Contemporary Research,. "Asia Pacific Institute of Advanced Research (APIAR) Nurturing Knowledge Without Boundaries. Volume 2 May 2019”, Australia 2019. (References)

[6] R. J. Lewicki, B. Barry, David M. "Negosiasi”. Salemba Humanika, Jakarta.2013.

[7] Berg, Riekke and R. Nirmala (ed),. "Transforming Local Political Leadership". Pelgrave McMillan, New York. 2005

[8] J. Kaloh,. "Mencari bentuk Otonomi Daerah: Suatu Solusi dalam Menjawab Kebutuhan Lokal dan Tantangan Global”. Rineka Cipta, Jakarta. 2002.

[9] Littlejohn, W. Stephen and A. Karen Foss. "Teori Komunikasi: Theories of Human Communication”. Salemba Humanika, Jakarta. 2009 .

[10] Taewoo Nam,. "A tool for liberty or oppression? A cross-national study of the Internet's influence on democracy". Department of Public Administration, Sungkyunkwan University, Sungkyunkwan-ro 25-2, Jongno-gu, Seoul 03063, Republic of Korea. Elsevier, Telematics and Informatics. 2016.

[11] P. Bourdieu, \& James S. Colemen (eds),. Social Theory for Changing Society. (Russell Sage Publication, New York). 1991. (References)

[12] P. Bourdieu,. The Field of Cultural Production: Essay on Art and Literature. (Columbia University Press). 1993.

[13] Ogbonna, Emmanuel and Harris, C. Lloyd, "Leadership Style, Organizational Culture and Performance: Empirical Evidence From UK Companies," International Journal of Human Resource Management 11:4 August, 2000. p. 766-788.

[14] L.L Kaid. "Handbook Penelitian Komunikasi Politik". Nusa Media, Bandung. 2015. (References)

[15] Kenneth Alan Bollen. "Liberal Democracy Series I, 1972-1988 Definition, measurement, and trajectories". Department of Sociology, University of North Carolina at Chapel Hill, 155 Hamilton Hall CB\# 3210, Chapel Hill, NC 27599-3210, United States. Elsevier, Electoral Studies. 2009.
[16] Choi, Nankyung. Democracy and Patrimonial Politics in Local Indonesia. Cornell University Press; Southeast Asia Program Publications at Cornell University, No. 88 (Oct., 2009), 2009. pp. 131 164

[17] Jean-François Daoust, Richard Nadeau. "Economics, politics and satisfaction with democracy". Department of Political Science, Universite de Montreal. CP 6128, Succ. Centre-ville, Montreal, Quebec, H3C 3J7, Canada. Politics and International Relations, University of Edinburgh, 15a George Square, EH8 9LD, Scotland, United Kingdom. Elsevier, Electoral Studies. 2020.

[18] C.K Jha, K.T. Oasis, "Does social media promote democracy? Some empirical evidence". Madden School of Business, Le Moyne College, 1419 Salt Springs Department Road, Syracuse, NY 13214, USA of Economics, University Of Kinshasa, Kinshasa, Congo. Elsevier, ScienteDirect, Journal of Policy Modeling. 2019.

[19] Y. Tarverdi, S. Saha, N. Campbell. "Governance, democracy and development". Curtin Business School, Curtin University, Australia, Lincoln International Business School, University of Lincoln, United Kingdom, Bond Business, School Bond University, Australia, Elsevier, Economic, Analysis and Policy. 2019.

[20] D. Bol, A. Blais, X. Gillard, L.N Lopez, J.B Pileta. "Voting and satisfaction with democracy in flexible-list PR" King's College London, United Kingdom, Université de Montréal, Canada, Université libre de Bruxelles, Belgium, IDEA Consult, Belgium. Elsevier, Electoral Studies. 2018

[21] A.C. Patterson, G. Veenstra,. "Politics and population health: Testing the impact of electoral democracy." Prentice Institute for Global Population and Economy, University of Lethbridge, 4401 University Dr W, Lethbridge, AB T1K3M4, Canada. Department of Sociology, University of British Columbia, 6303 NW Marine Dr, Vancouver, BC V6T1Z1, Canada. Elsevier, Health and Place. 2016.

[22] Z. Asatryan, T. Baskaran, F. Heinemann. The effect of direct democracy on the level and structure of local taxes. ZEW Mannheim, L7 1, 68161 Mannheim, Germany, University of Siegen, Germany, University of Heidelberg, Germany. Elsevier, Regional Science and Urban Economics. 2018

[23] S. Strunz, B. Bartkowski. "Degrowth, the project of modernity, and liberal democracy". Helmholtz Centre for Environmental ResearchdUFZ, Permoserstr. 15, 04318, Leipzig, Germany. Elsevier, Journal of Cleaner Production. 2018.

[24] A. DeVelasco, R. E. Denton, Jr.. "The Production of Political Transcendence in the Clinton Presidency". Lexington Studies in Political Communication, Lexington Books, Virginia Polytechnic Institute and State University. 2010.

[25] D. G. Lilleker. "Political communication Key Concepts in Political Communication" SAGE Publications Ltd 1 Oliver's Yard 55 City Road London EC1Y 1SP Printed in Great Britain by Cromwell Press Ltd, Trowbridge, Wilts. 2006.

[26] D. E. Apter,. "Duchamp's Urinal: Who Says What's Rational When Things Get Though?" dalam Robert E. Goodin \& Charles Tilly (eds), The Handbooks of Political Science: Contextual Political Analysis. (Oxford University Press), pp. 777-781. 2006

[27] K. Brants and K. Voltmer. "Political Communication in Postmodern Democracy Challenging the Primacy of Politics". First published by PALGRAVE MACMILLAN Palgrave Macmillan in the US is a division of St Martin's Press LLC, 175 Fifth Avenue, New York, NY 10010. 2011. 